\title{
COMPOUNDS DERIVED FROM GARLIC AS BUD INDUCTION AGENTS IN ORGANIC FARMING OF TABLE GRAPE
}

\author{
Irasema Vargas-Arispuro ${ }^{1}{ }^{*}$, Consuelo Corrales-Maldonado ${ }^{1}$, and \\ Miguel Ángel Martínez-Téllez ${ }^{1}$
}

\begin{abstract}
A B S T R A C T
Viticulture is one of the most important economic activities in the Northwest of Mexico. A major obstacle for the economic production is the insufficient period of chilling temperatures. This problem leads to poor budbreak, which in turn results in reduced yields. This problem is aggravated when plants are cultivated using the organic farming system, mostly because there are not organically approved restbreaking agents. In this work different products derived from garlic $(\mathrm{Al}$ lium sativum $\mathrm{L}$.) were obtained and evaluated as stimulate budbreak agent of table grape (Vitis vinifera L.) cvs. Flame Seedless and Perlette. The isolated compounds were chemically identified and include allicin, diallyl disulfide, diallyl trisulfide, 3-vynil-[4H]1.2-ditiin and 2-vynil-[3H]-1.3-ditiin, S-methyl cysteine sulphoxide, dimethyl disulfide, dimethyl trisulfide and dimethyl thiosulfonate. Cuttings with six buds were used to evaluate the compounds. After compounds were applied, the cuttings were transferred to a growing chamber at $24^{\circ} \mathrm{C}$. All evaluated compounds promoted budbreak in the cuttings of Flame Seedless and Perlette. The volatile compounds from S-methyl cysteine sulfoxide promoted $100 \%$ of budbreak of both cultivars. The compounds from garlic that stimulated budbreak in grapevines in this work include sulphur in their molecule; therefore we propose that sulphur could play a key role in breaking bud dormancy of grape cultivars evaluated in this study.
\end{abstract}

Key words: Vitis vinifera, Flame Seedless, Perlette, budbreak, allicin, S-methyl cysteine sulfoxide, Allium sativum.

\section{INTRODUCTION}

The world market for organic fruit and vegetable products has been growing rapidly in recent years, with the greatest demand coming from the member countries of the European Economic Community, the United States, Canada and Japan (Dimitri and Oberholtzer, 2006). It is estimated that the demand from these countries for organic products will increase by $15-20 \%$ per year over the next few years (Kortbech-Olesen, 2006), creating an opportunity to motivate agricultural producers to adopt organic methods to cultivate fruit and vegetables aimed at these markets, thus obtaining the benefit of higher prices.

A limiting factor of organic agriculture for some agricultural regions is the reduced number of authorized inputs, which puts the profitability of the industry at risk. Specifically, this applies to the cultivation of the grapevine (Vitis vinifera L.) for the production of table grapes, established in agricultural regions with temperate climates, where the warm autumns and winters lead to uneven and/or unproductive budding, owing to the insufficient cold. This can reduce production up to $50 \%$ when chemicals that induce bud breaking are not applied. (Or et al., 1999).

In conventional agriculture, the lack of effects caused because of cold in grapevine plants are reduced with the application of hydrogen cyanamide and/or calcium cyanamide, effective chemical agents for inducing bud breaking among several species of deciduous plants (Lavee and May, 1997). Nevertheless, these bud breaking inducing agents are not authorized for use in organic cultivation.

\footnotetext{
${ }^{1}$ Centro de Investigación en Alimentación y Desarrollo, A.C. Carr. a la Victoria km 0,6, 83000 Hermosillo, México. E-mail: iris@cascabel.ciad.mx *Corresponding author. Received: March 21, $2007 . \quad$ Accepted: July 20, 2007.
} 
Among the permitted products in organic agriculture are sulphur and its derivatives, such as extracts from garlic (Allium sativum L.) (NCFAP, 2001; OMRI, 2006). The compounds obtained from garlic are mainly derivatives of sulphur (Jirovetz et al., 2001). As well, there are reports that a paste prepared from fresh garlic induces bud breaking in a manner similar to calcium cyanamide, when applied to grapevine buds with insufficient cold (Kubota et al., 2000).

In the present experiment, isolated volatile and nonvolatile compounds extracted from fresh garlic were evaluated for use in inducing bud breaking in cuttings of grapevines of the varieties Flame Seedless and Perlette, cultivated in the Northeast of Mexico, a region with warm winters where practices to obtain early harvests are highly desirable.

\section{MATERIALS AND METHODS}

Vegetal material. The cuttings were collected from adult grapevine plants (Vitis vinifera L.), cvs. Perlette and Flame Seedless in dormancy, with $140 \mathrm{~h}$ of naturally accumulated cold. The vegetal material came from a commercial vineyard in the agricultural zone of Pesquira, Sonora $\left(29^{\circ} 22^{\prime} \mathrm{N}\right)$, Mexico. The experiments were carried out in the Vegetal Physiology and Chemical Ecology Laboratory of the Center on Food and Development, in Hermosillo, Mexico. Cuttings with six buds were used to evaluate the effects of garlic derivatives.

Obtaining garlic extracts. Extracts were obtained from $100 \mathrm{~g}$ of fresh garlic cloves that were mashed in a porcelain mortar (Kubota and Miyamuki, 1992). The resulting paste was termed garlic extract.

Obtaining of allicin. The allicin compound was obtained from $5 \mathrm{~g}$ of fresh garlic cloves, homogenized in $30 \mathrm{~mL}$ of distilled water for $5 \mathrm{~min}$ at $4{ }^{\circ} \mathrm{C}$. The homogenized result was incubated at $30^{\circ} \mathrm{C}$ for $20 \mathrm{~min}$. Following incubation, it was subjected to centrifugation for $20 \mathrm{~min}$ at $15000 \mathrm{~g}$ at $4{ }^{\circ} \mathrm{C}$, after which $1.5 \mathrm{~mL}$ of methanol was added, repeating the centrifugation for $5 \mathrm{~min}$ at $4{ }^{\circ} \mathrm{C}$. The allicin was isolated using high resolution liquid chromatography (HPLC) linked to a diode array detector (Hewlet-Packard Co., HP-1100, Wilmington, Delaware, USA) and a refraction index indicator (Hewlett-Packard, HP 1047A, Tokyo, Japan). The equipment was controlled by the ChemStation program (ChemStation software for LC, GC, Hewlett-
Packard, A.06.0X. 76337, Waldbronn, Germany). The column used was a Hyper-sil ODS (250 x 4.6 mm, 5 $\mu$, Agilent Technologies, Santa Clara, California, USA). The conditions of detection of allicin in HPLC were a mobile phase of methanol $(60 \%)$ : water (for-

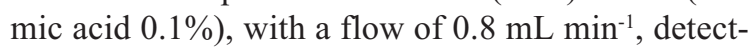
ing the sample at the wavelength of $254 \mathrm{~nm}$. The chemical identification of the product was based on the conjunction of data, such as the retention time in HPLC, which was $6.5 \mathrm{~min}$, the mass fragmentation, the ultraviolet spectrum, which coincided with the characteristics of a commercial standard (Chromadot, Sigma Co., Palo Alto, California, USA) prepared at $10 \mathrm{mg} \mathrm{mL}^{-1}$ in accordance to what was described by Rybak et al., 2004.

Obtaining allicin volatiles. The volatiles were generated from the allicin obtained as described in the previous paragraph. Five $\mathrm{mL}$ of allicin was left in a hermetically sealed vial for $72 \mathrm{~h}$ at room temperature. The volatiles generated were recovered and identified in a direct injection gas chromatographer (Star 3400 CX, Varian, Palo Alto, California, USA), joined to an electronic impact mass detector (Saturn III, Varian, Palo Alto, California, USA). The column used was DB-1 (Agilent Technologies) of $30 \mathrm{~m} \times 0.25 \mathrm{~mm}$ of internal diameter. The temperature program was from 30 to $100{ }^{\circ} \mathrm{C}$, with increments of $2{ }^{\circ} \mathrm{C} \mathrm{min}^{-1}$, the transference line and the ion trap were programmed at $100{ }^{\circ} \mathrm{C}$.

\section{Obtaining S-methyl cysteine sulfoxide (SMCSO).} This was obtained from $200 \mathrm{~g}$ of fresh garlic cloves soaked with methanol at $95 \%$ for three days at room temperature. Over this time it was homogenized and filtered through Whatman filter paper \# 4. The filtered result was concentrated in a rotary evaporator. The extract obtained (16 g) was separated in a chromatographic column filled with resin (AG-50WX2), elucidated with amonia hydroxide $1 \mathrm{~N}$ the fraction that contains the SMCSO (Corrales-Maldonado, 2004). The fraction was concentrated and the SMCSO was purified and identified using the HPLC equipment described for obtaining allicin. The column that was utilized was Lichrosphere 5 RP-18 $(25 \times 10,5 \mu)$ (Phenomenex, Torrance, California, USA). It was worked with an isocratic method with a mobile phase with $16 \%$ of acetonitrile in a buffer of potassium phosphate 50 $\mathrm{mM}$ (pH 7.0). The detection was made at $337 \mathrm{~nm}$ in accordance to what was proposed by Marks (1992). 
Obtaining volatiles of S-methyl cysteine sulfoxide. The volatiles were generated based on the SMCSO obtained as described in the previous paragraph. The SMCSO was degraded thermically in conditions of autoclave at $121^{\circ} \mathrm{C}$ for $15 \mathrm{~min}$. The volatiles generated were recuperated and identified in the same manner as the volatiles of allicin. The column utilized was DB-1 (30 m x $0.25 \mathrm{~mm}$, Agilent Technologies). The oven temperature was programmed from 40 to $200{ }^{\circ} \mathrm{C}$ with increments of 2.4 ${ }^{\circ} \mathrm{C} \mathrm{min}^{-1}$. The temperatures of the injection port and of the detector were 250 and $280{ }^{\circ} \mathrm{C}$, respectively. The ion source was $70 \mathrm{eV}$ and was worked in a range of masses from 40 to $200 \mathrm{Da}$ (Kyung et al., 1997).

Treatments. The products derived from garlic were applied to 10 cuttings per treatment (six buds per cutting) of the cultivars Perlette and Flame Seedless. The treatments were applied directly on the buds with the aid of a cotton swab impregnated with the different products, which were: garlic extract, allicin, volatiles of allicin, SMCSO, volatiles of SMCSO, $4 \%$ hydrogene cyanamide that was used as a positive control, and as absolute control cuttings without any application were used. After the application of the treatments, the cuttings were placed in containers with the cut stems submerged in water. The containers were transferred to a growth chamber with a controlled temperature of $24 \pm 2{ }^{\circ} \mathrm{C}$, and a photoperiod system of 16:8 h light:h of darkness. The cuttings remained in the chamber until the end of the experiment. Bud breaking was considered to have occurred when green buds appeared. A daily record was kept of the buds to register the percentage of bud breaking per day over a period of 35 days.

To analyze the effect of the compounds on bud breaking a variance analysis was carried out, with repeated measurements of the data on breaking buds. To do this, the statistical package Number Cruncher Statistical System (NCSS) was used (Hintze, 2001). The averages were compared using the Tukey test $(\mathrm{P}<0.05)$.

\section{RESULTS AND DISCUSSION}

\section{Identification of compounds derived from garlic}

Two non-volatile compounds were extracted from fresh garlic. The first was identified allicin, which is a highly unstable compound at room temperature. Taking advantage of this instability, the thermic degradation of the obtained allicin was induced in order to form a mix of volatile compounds. Some of the most abundant compounds in the mix of volatiles were dimethyl disulfide, dimethyl trisulfide, 3-vinil-[4H]-1,2-ditiin and 2-vinil-[3H]-1,3-ditiin (Figure 1). These compounds had previously been reported on as derivatives of garlic (Kubota et al., 1999; 2000).

Durenkamp and De Kok (2004) made a review of how sulphur compounds are involved in multiple biological activities of plants. Both allicin and volatile compounds were evaluated in the inducement of bud breaking of grapevines.

The second non-volatile compound obtained in this work was identified as S-methyl cysteine sulfoxide (SMCSO), the pattern of mass fragmentation coinciding with what was indicated in the literature for this compound which showed the molecular ion of 151 Da (Kyung et al., 1997). In the mix of volatiles generated from SMCSO, three compounds of greater concentration were identified: dimethyl disfulfide, dimethyl trisulfide and dimethyl sulfide; their gas chromatogram is shown in Figure 2. These compounds were reported by Kubec et al. (1998) as precursors of sulphur (S-) in vegetables of the genus Brassica and Allium.

\section{Effect of compounds derived from garlic in the induction of bud breaking of grapevine buds}

The effect of garlic derivatives was measured, quantifying the percentage of bud breaking after applying the different products on the buds; hydrogen cyanamide at $4 \%$ was used as a positive control. The buds of cv. Perlette began breaking six days after the application win all of treatments, advancing breaking by 3 days in comparison with the control (Figure 3). The percentage of active buds reached $100 \%$ at 25 days after the application of the treatments of SMCSO, the mix of volatiles and hydrogen cyanamide. At 35 days, the treatments of volatiles of allicin, garlic extract, allicin, and the control accumulated percentages of bud breaking of $80,73,45$ and $25 \%$, respectively (Figure 3 ). Although the treatment with allicin presented a bud breaking of $20 \%$ greater than with the control, it resulted statistically the same.

In the buds of cv. Flame Seedless (Figure 4) the initiation of bud breaking was advanced with all the treatments in relation to the control. Bud breaking was present between 18-20 days after the applica- 


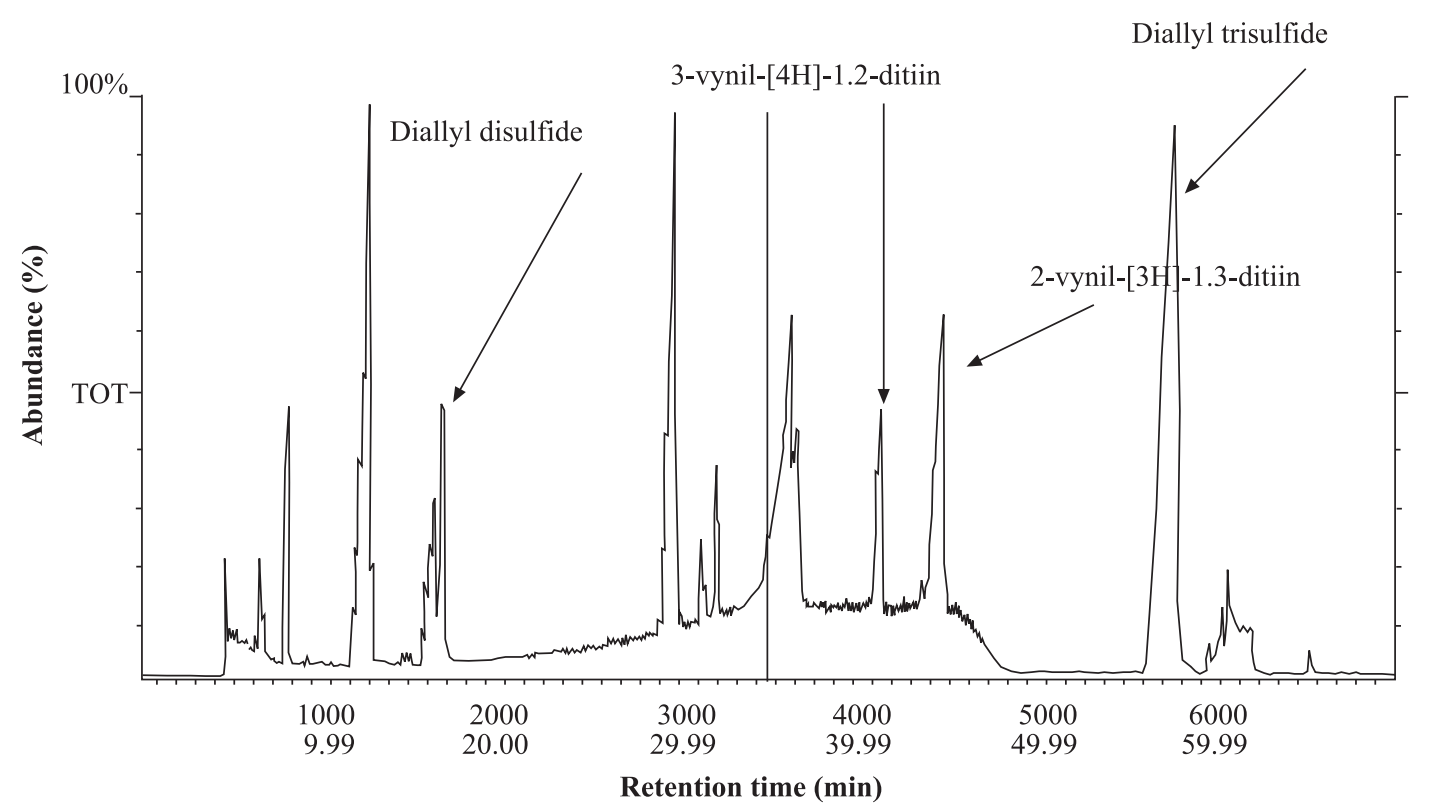

Figure 1. Gas/mass chromatogram of volatile compounds from allicin.

tion of the treatments; the control began bud breaking at 34 days, which meant that the products advanced bud breaking by between 14-16 days in relation to the control. The treatment with volatiles of SMCSO reached $100 \%$ of bud breaking at 35 days after the application, at the same time when the control was beginning bud breaking. The treatments of garlic extract, SMCSO, volatiles of allicin and cyanamide, caused a percentage of bud breaking between $62-70 \%$, which resulted statistically equal. The treatment of allicin induced $92 \%$ of bud breaking toward the end of the evaluation. With this cultivar, the lowest percentage of bud breaking was observed with the control, with $23 \%$.

The buds of $\mathrm{cv}$. Perlette presented a better response to the application of the two garlic derivatives than the buds of cv. Flame Seedless; which could be because these cultivars have different requirements of cold hours for bud breaking, 150-200 h being the requirement for cv. Perlette and 300-350 h for v. Flame Seedless, which means that the buds of the two cultivars are in different states in the dormancy cycle when the treatments are applied, favoring cv. Perlette, given that when the cuttings were collected in the field, they had $140 \mathrm{~h}$ of accumulated cold in both cultivars, which can explain why cv. Perlette began bud breaking in less time than cv. Flame Seedless.
In the two cultivars evaluated, the volatiles of SMCSO induced $100 \%$ of bud breaking. The induction of bud breaking in grapevines by the effect of volatiles of SMCSO has not been reported previously. Among the volatiles, dimethyl disulfide was identified as one with greater concentration in the mix of volatiles (Figure 2). Kubota et al. (2003) reported that exposure to volatiles obtained from leaves of Allium tuberosum Rottler ex. Spring and from Allium chinense G. Don, dimethyl disulfide was one of the compounds responsible for breaking dormancy in the grapevine cv. Kyoho, from which it can be inferred that the effect of inducing bud breaking from the treatment of SMCSO volatiles can be related to the presence of dimethyl disulfide.

Treatment with volatiles of allicin promotes bud breaking in a similar way to the effect of cyanamide in both cultivars, this response coinciding with what was observed by Kubota et al. (2000) in el cv. Pione, to induce bud breaking with dimethyl disulfide and dimethyl trisulfide. These two substances were identified in this work among the volatiles generated through the thermic degradation of allicin (Figure 1), such that the effect of volatiles of allicin to induce bud breaking could be attributed to the presence of these two compounds. 


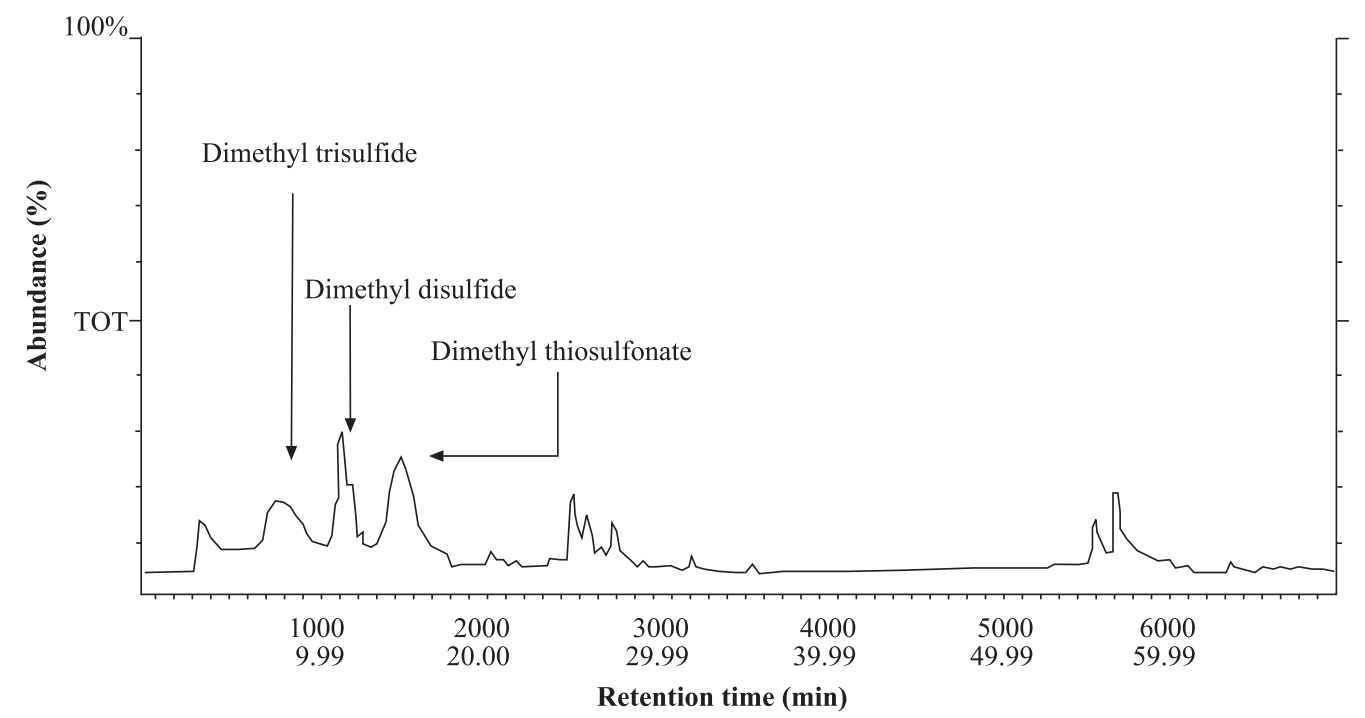

Figure 2. Gas/mass chromatogram of volatile compounds from S-methyl cysteine sulfoxide (SMCSO).

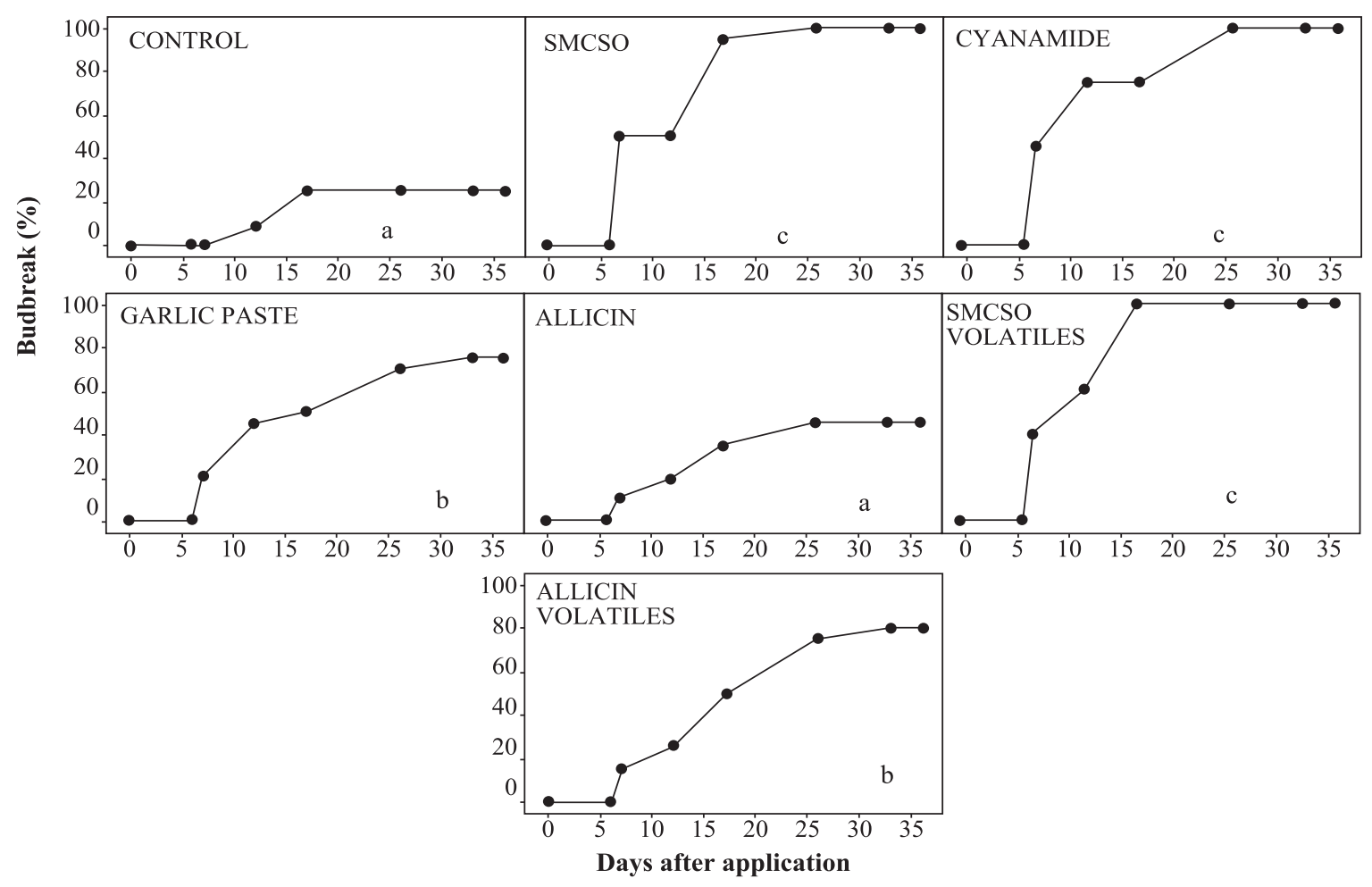

Figure 3. Effects of application of derivatives of garlic on budbreak of tablegrape cv. Perlette.

Different letters on each treatment are significantly different Tukey $(\mathrm{P}<0.05)$. The results were similar in experiments repeated at least two times. 


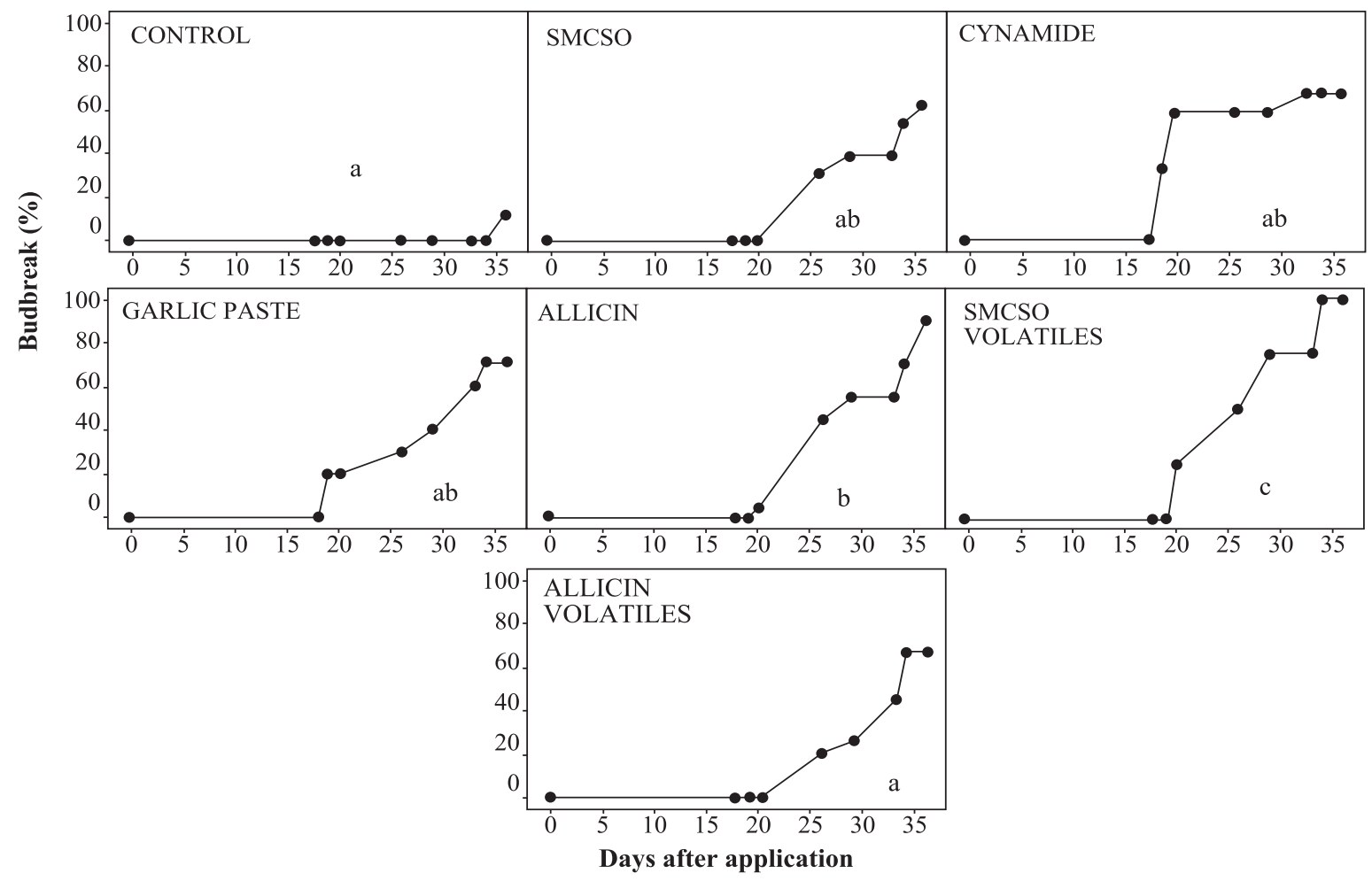

Figure 4. Effects of application of derivatives from garlic on budbreak of tablegrape cv. Flame Seedless.

Different letters on each treatment are significantly different Tukey $(\mathrm{P}<0,05)$. The results were similar in experiments repeated at least two times.

Every product derived from garlic obtained and evaluated in this study contains at least one atom of sulphur in its molecule. The volatile compounds contain two, three or more atoms of sulphur, while the non-volatiles contain fewer atoms of sulphur than the volatile compounds. Substances with sulphur molecules have been attributed with the effect of interrupting the dormancy of different species of deciduous plants (Hartmann et. al., 2000). Dimethyl disulfide has specifically been identified as responsible for this effect (Kubota et al., 2003). The volatile compounds that have two, three or more atoms of sulphur, presented greater effect on bud breaking than non-volatile compounds. The mechanism by which sulphur compounds can induce bud breaking continues to be unknown. However, progress has been made in elucidating the implied routes in the regulation of sulphur in relation to the vegative growth of plants (Hawksford and De Kok, 2006). In the process of assimilation of sulphur by the plant, inorganic sulphur is fixed as cysteine after a process of reduction (Saito, 2000). Cysteine is the initial material for the pro- duction of reduced glutathione, which is responsible for detoxing cells through the elimination of free radicals and reactive species that accumulate during different types of stress (Saito, 2004; Zang, 2004). If the sulphur molecules derived from garlic can be assimilated by the plant in the latent stage, it can favor the detoxification of the plant and promote bud breaking. At the same time, exogenous applications of reduced glutathione induced bud breaking when it was applied on buds of grapevines of cv. Delaware (Tohbe et al., 1998), thus being a possible mechanism for increasing output of this tripeptide.

\section{CONCLUSIONS}

With the results obtained it is possible to conclude that the allicin and SMCSO isolated and identified in this work, as well as the mixes of volatiles generated by these two compounds, were capable of inducing bud breaking in cvs. Perlette and Flame Seedless, when these do not complete the requirements of accumulation of cold hours. All the 
treatments advanced bud breaking in relation to the control, highlighting the treatment of volatiles of SMCSO, which induced $100 \%$ bud breaking in both cultivars, with better results than hydrogen cyanamide. In this work the volatile compounds induced a greater percentage of bud breaking than the nonvolatile compounds.

Given that botanic agents are accepted in organic agricultural production, products derived from garlic can become an alternative input to induce bud breaking in the organic cultivation of table grapes in temperate regions with warm winters.

\section{ACKNOWLEDGEMENTS}

This project was carried out with the support of the Association of Table Grape Producers of the State of Sonoro, Mexico, and was financed by the Fundación Produce Sonora, as part of the Integral Grapevine Project.

\section{Compuestos derivados de ajo como agentes inductores de brotación en cultivo orgánico de uva de mesa}

\section{R E S U M E N}

La viticultura es una de las principales actividades económicas en el Noroeste de México. Entre los problemas que enfrenta esta actividad está el período de frío insuficiente, lo que lleva a una pobre brotación y consecuentemente una menor producción. Este problema se agrava cuando se cultivan plantas por el método orgánico, ya que no existen agentes inductores de brotación aprobados para uso orgánico. En este trabajo se aislaron diferentes compuestos derivados de ajo (Allium sativum L.) que se evaluaron para medir su efecto en la inducción de brotación de yemas de vid (Vitis vinifera L.) de los cultivares Flame Seedless y Perlette. Los compuestos aislados de ajo e identificados químicamente fueron: allicina, dialil disulfuro, dialil trisulfuro, 3-vinil-(4H)-1,2ditiin y 2-vinil-(3H)-1,3-ditiin, S-metilcisteína sulfóxido, dimetil disulfuro, dimetil trisulfuro y dimetil tiosulfonato. Se utilizaron estacas de seis yemas para la evaluación de los compuestos; después de la aplicación las estacas se desarrollaron en cámara de crecimiento a $24{ }^{\circ} \mathrm{C}$. Todos los compuestos evaluados promovieron la brotación de las yemas de ambos cultivares. Los compuestos volátiles de S-metilcisteína sulfóxido indujeron $100 \%$ de brotación. Los compuestos derivados de ajo que indujeron la brotación en este trabajo contienen azufre en su molécula, por lo que se deduce que el azufre puede tener un importante papel en el rompimiento de la dormancia de las yemas de vid de los cultivares evaluados en este estudio.

Palabras clave: Vitis vinifera, Flame Seedless, Perlette, brotación, allicina, S-metilcisteína sulfóxido, Allium sativum. 


\section{LITERATURE CITED}

Durenkamp, M. and L.J. De Kok. 2004. Impact of pedospheric and atmospheric sulphur nutrition on sulphur metabolism of Allium cepa L. a species with a potential sink capacity for secondary sulphur compounds. J. Exp. Botany 55:1821-1830.

Dimitri, C., and L. Oberholtzer. 2006. EU and U.S. organic markets face strong demand under different policies. Amberwaves. Economic Research ServiceUSDA 4:12-19.

Corrales-Maldonado, C. 2004. Control in vitro de Phymatotrichopsis omnivora por compuestos azufrados aislados de plantas del género Brassica. p. 19-21. Tesis de Maestría. Centro de Investigación en Alimentación y Desarrollo, A.C., Hermosillo, Sonora, México.

Hartmann, T., S. Mult, M. Suter, H. Rennenberg, and C. Herschbach. 2000. Leaf age-dependent differences in sulphur assimilation and allocation in poplar (Populus tremula $\times$ P. alba) leaves. J. Exp. Botany 51:1077-1088.

Hawkesford, M., and L. de Kok. 2006. Managing sulphur metabolism in plants. Plant Cell and Envirom. 29:382395.

Hintze, J. 2001. Number cruncher statistical system. Statistical software version 6.0. NCSS, Kaysville, Utah, USA.

Jirovetz, L., M. Ngassoum, and G. Buchbauer. 2001. Analysis of garlic (Allium sativum) aroma compounds using SPME-GC-FID, SPME-GC-MS and olfactometry. Rec. Res. Devl. Agric. Food Chem. 5:144-148.

Kortbech-Olesen, R. 2006. The United States market for organic food and beverages. International Trade Center Report. Available at http://www.intracen.org/ mds/sectors/organic Accessed 2 March 2006.

Kubec, R., V. Drhová, and J. Velíšek. 1998. Thermal degradation of S-methylcysteine and its sulfoxideimportant flavor precursors of Brassica and Allium vegetables. J. Agric. Food Chem. 46:4334-4340.

Kubota, N., M.A. Matthews, T. Takahagi, and W.M. Kliewer. 2000. Budbreak with garlic preparations. Effect of garlic preparations and of calcium and hydrogen cyanamides on budbreak of grapevines grown in greenhouses. Am. J. Enol. Vitic. 51:409414.

Kubota, N., and M. Miyamuki. 1992. Breaking bud dormancy in grapevines with garlic paste. J. Am. Soc. Hortic. Sci. 68:1111-1117.
Kubota, N., K. Tpriu, Y. Yamane, K. Kawazu, T. Higuchi, and S. Nishimura. 2003. Identification of active substance in Chinese chive and rakkyo plants responsible for breaking bud dormancy in grape cutting. J. Japan. Soc. Hort. Sci. 72:268-274.

Kubota, N., Y. Yamane, K. Toriu, K. Kawazu, and T. Higuchi. 1999. Identification of active substances in garlic responsible for breaking bud dormancy in grapevines. J. Japan. Soc. Hort. Sci. 68:1111-1117.

Kyung, H. K., D.C. Han, and H. P. Fleming. 1997. Antibacterial activity of heated cabbage juice, Smethyl-L-cysteine sulfoxide and methyl methanethiosulfonate. J. Food Sci. 62:406-409.

Lavee, S. and P. May. 1997. Dormancy of grapevine buds: facts and speculation. Austr. J. Grape and Wine Res. 3:31-46.

Marks, H.S. 1992. S-methylcysteine sulfoxide in Brassica vegetables and formation of methyl methanethiosulfinate from Brussels sprouts. J. Agri. Food Chem. 40:2098-2101.

NCFAP. 2001. National Pesticides Use Database. National Center for Food and Agricultural Policy (NCFAP). Available at http://www.ncfap.org/ncfap/index.html Accessed 2 March 2006.

OMRI. 2006. Organic products list. Organic Materials Review Institute (OMRI). Available at http:// www.omri.org Accessed 10 March 2006.

Or, E., G. Nir, and I. Vilozny. 1999. Timing of hydrogen cyanamide application to grapevine buds. Vitis 38:1-6.

Rybak, M., E. Calvey, and J.M.Harnley. 2004. Quantitative determination of allicin in galic: supercritical fluid extraction and standars addition of allicin. J. Agric.Food. Chem.52:682-687.

Saito, K. 2000. Regulation of sulfate transport and synthesis of sulfur-containing amino acids. Curr. Opin. Plant Biol. 3:188-195.

Saito, K. 2004. Sulfur assimilatory metabolism. The long and smelling read. Plant Physiol. 136:2443-2450.

Tohbe, M., R. Mochioka, R. Horiouchi, S. Ogata, T. Shiozaki, and S. Kurooka. 1998. Roles of ACC and glutathione during breaking of dormancy in grapevine buds by high temperature treatment. J. Japan. Soc. Hort. Sci. 67:897-901.

Zhang, M., A. Bourbouloux, O. Cagnac, C. Srikanth, D. Rentsch, A. Bachhawat, et al. 2004. A novel family of transporters mediating the transport of glutathione derivates in plants. Plant Physiol. 134:482-491. 